\title{
Biogas Perspectives in Livestock Sector in Brazil and the United States: Electric, Thermal and Vehicular Energy Use
}

\author{
Janaina Camile Pasqual $^{1}$, Harry Alberto Bollmann ${ }^{1}$ and Christopher Scott ${ }^{2}$ \\ 1. Urban Management Program, Pontifical Catholic University of Paraná (PUCPR), Curitiba, Paraná 80215-901, Brazil \\ 2. Udall Center for Studies in Public Policy and School of Geography \& Development, University of Arizona, Tucson, AZ 85719, \\ United States
}

\begin{abstract}
The demand for energy, water and food will continuously increase, as the prediction states that 2.5 billion people will be added to the world population by 2050, representing not only an increase in the consumption but also more waste production, greenhouse gas (GHG) emissions and depletion of natural resources. Taking into account that renewable sources of energy can help to overcome these challenges and diversify the energy matrix in the countries, this paper aims at analyzing the biogas potential in Brazil and the United States, especially in the livestock sector, and its benefits in the environmental, social and economic aspects. Both countries are among the top five countries globally in terms of water availability, energy consumption and food production. Until 2050, the world consumption of meat will have a significant increase: $206 \%$ of poultry meat, $56 \%$ of pork meat and $47 \%$ of beef meat, augmenting the need for sustainable management of waste and manure. This scenario can become a sustainable opportunity for biogas implementation, which provides multiple economic, environmental and social benefits for farmers, businesses and communities, including production of electrical, thermal and vehicular energy, production of high-quality biofertilizer, reduction of ground and surface water pollution and reduction of GHG emissions, and foments new income for the farmers, among others. A new concept is presented in this article to make biogas systems feasible, i.e., biogas condominiums, as small and medium-scale farms by themselves usually would not be able to afford the investments. This arrangement can bring benefits for the whole biogas supply chain that includes farmers, agroindustry, providers and local community.
\end{abstract}

Key words: Biogas condominiums, biomethane, livestock, climate changes.

\section{Introduction}

The continued world population growth until 2050 is inevitable, even with the decline of human fertility. The United Nations Department of Economic and Social Affairs estimates that the population will be 8.6 billion in 2030 and 9.4-10 billion in 2050 [1], demanding a food production increase of $60 \%$ and requiring $45 \%$ more energy and 30\% more water (19\% increase of agricultural water consumption) [2]. To accommodate this population, cities need to become more organized and sustainable to ensure health and education, manage and optimize natural resources to

Corresponding author: Janaina Camile Pasqual, Ph.D. student, research fields: water-energy-food nexus, biogas and biomethane. produce the required energy and food, protect the environment and adapt to climate changes as well [3].

Among the main countries to meet this demand, Brazil and the United States (US) present favorable conditions for increasing their production, as they are among the five countries with the largest territorial extent, are leaders in food production and have abundant water and land availability. Besides these conditions, other factors needs to be considered, such as productive and efficient technologies used in their process for energy and food production, mitigating the asymmetric pressure on the water resources.

According to Rodrigues et al. [4], the growing concern about environmental quality, climate change and depletion of fossil resources for energy generation 
has led countries to use agriculture and livestock as an important source of renewable resources for clean energy generation. Eisler et al. [5] sustain that "with animal protein set to remain part of the food supply, we must pursue sustainable intensification and figure out how to keep livestock in ways that work best for individuals, communities and the planet”.

At this juncture, one technology that integrates the water-energy-food nexus is biogas [3], which stands as a systemic source of energy generated by the proper treatment of animals, vegetables, human and industrial wastes. Biogas can also transform environmental liabilities into economic assets through two results: directly through the generation of electric, thermal and vehicular energy (biomethane) and bio-fertilizer; indirectly with the reduction of greenhouse gases (GHG) emissions and thereby mitigating global warming. Unlike intermittent renewable energy alternatives, such as wind and solar power, biogas supplies a continuous source of energy with a very high capacity factor, which is calculated by dividing the total amount of energy the plant produced during a period of time and the amount of energy the plant would have produced at full capacity. For these reasons, biogas systems have become a focal topic for many local, state and national policymakers, and the organic waste is today recognized as a resource to use rather than a problem to manage.

This article presents the biogas outlooks for Brazil and the US, focusing on the livestock sector, and the benefits of this source of energy in the environmental, social and economic aspects. Both countries present very similar scenarios regarding the opportunities for use of this energy source: among the five countries with the largest population and territorial extent, leaders in food production, large energy consumers and among the countries with greater availability of water in the world.

\section{Biogas: Benefits and Limitations}

Biogas is a biofuel produced from the decomposition of organic matter (organic waste) by bacteria. It is defined as the gas product from anaerobic digestion. Briefly, the biogas production starts with the concentration of the organic material into a digester system. The anaerobic degradation of this organic substrate is a fermentative and oxidative process, which happens under anaerobic conditions, that is in the absence of oxygen. The organic material is broken down and the biogas is produced, composed mainly by methane, which can be converted into electric, thermal and vehicular energies. The digested material (solid and liquids) can be used as fertilizer to increase agricultural productivity (Fig. 1).

The primary biogas system feedstock can be obtained from:

(a) Municipal solid waste: mixed municipal solid waste delivered to landfill (about 30\% organics);

(b) Wastewater biosolids and primary sludge: by-product of water recovery treatment process;

(c) Food loss and waste: the amount of edible food that is available for human consumption, but is not consumed for any reason;

(d) Food production residuals: by-products of the food production and processing industry;

(e) Livestock manure: dairy, swine, poultry and beef.

Biogas is mainly composed of methane, which lifetime in the atmosphere is much shorter than $\mathrm{CO}_{2}$, but $\mathrm{CH}_{4}$ is more efficient at trapping radiation than $\mathrm{CO}_{2}$. According to Metcalf \& Eddy [6], biogas may contain water vapor traces ( $\mathrm{H}_{2} \mathrm{O}$ vapor), $\mathrm{H}_{2} \mathrm{~S}, \mathrm{~N}_{2}, \mathrm{O}_{2}$, $\mathrm{H}_{2}$, CO and $\mathrm{NH}_{3}$, as shown in Table 1. Pound for pound, the comparative impact of methane on climate change is more than 25 times greater than $\mathrm{CO}_{2}$ over a 100-year period [7, 8].

Successful biogas systems have a great potential to capture methane that would escape into the atmosphere and utilize it to create energy (e.g., electricity, heat, vehicle fuel) and non-energy products, such as nutrient rich soil amendments, pelletized and pumpable fertilizers/digestate, and even feedstock for plastics and chemicals. 


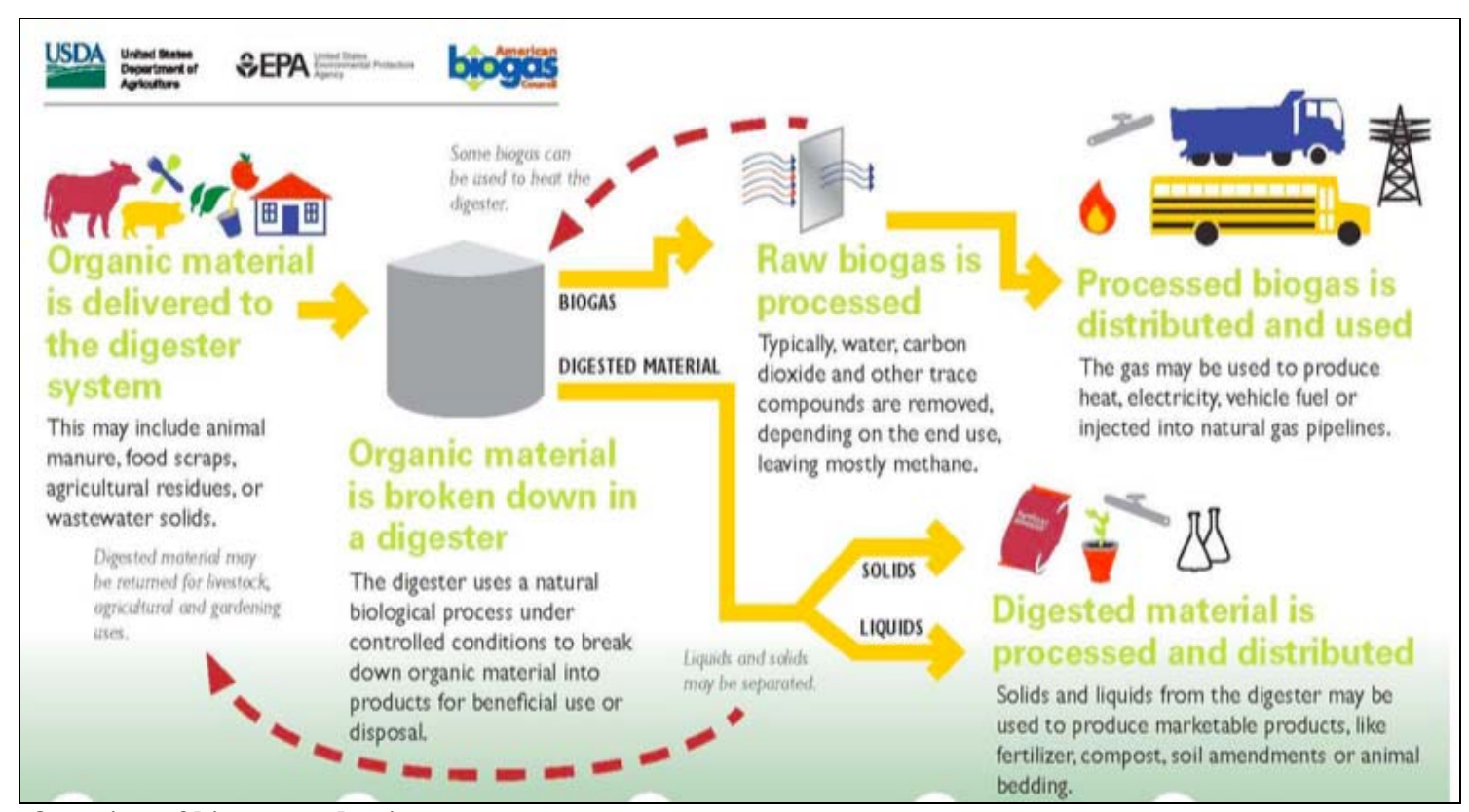

Fig. 1 Overview of biogas production process.

Source: USDA, 2014 [9].

Table 1 Main gases that compose biogas.

\begin{tabular}{lll}
\hline Gas & Symbol & Concentration in biogas \\
\hline Methane & $\mathrm{CH}_{4}$ & $50 \%-80 \%$ \\
Carbon dioxide & $\mathrm{CO}_{2}$ & $20 \%-40 \%$ \\
Hydrogen & $\mathrm{H}_{2}$ & $1 \%-3 \%$ \\
Nitrogen & $\mathrm{N}_{2}$ & $0.5 \%-3 \%$ \\
Hydrogen sulfide and others & $\mathrm{H}_{2} \mathrm{~S}, \mathrm{CO}, \mathrm{NH}_{3}$ & $1 \%-5 \%$ \\
\hline
\end{tabular}

Source: Coldebella [10].

Biogas can be produced on a small scale in a biogas generator/digester, which can be made of simple materials, or in large scales using more advanced technologies to control the digestion. Several factors, such as project goals, local energy policies, infrastructure availability and markets for renewable energy products, will dictate what end use best fits the project. Each system includes the infrastructure to manage the organic wastes as well as the equipment to generate energy from the resulting biogas. These systems have been used on a commercial scale in Brazil and in the US since the late 1970s, when concerns over energy prices and dependence on oil spurred the interest in the use of recovered biogas as a source of energy [9].

\subsection{Benefits}

Biogas processes can provide multiple economic, environmental and social benefits. These benefits are diverse and multifaceted. They include, but are not limited to, the following:

\subsubsection{Environmental Benefits}

Some important biogas environmental benefits are:

(a) The appropriate waste management, converting into biogas, can mitigate ground and surface water pollution, air and solid contamination. Biogas generation does not require any intervention into nature and does not pose threats for biodiversity loss [11];

(b) Capture of uncontrolled methane emission, thus reduction of GHG emissions. The reduction of $1 \mathrm{~kg}$ of methane is equivalent to the reduction of $25 \mathrm{~kg}$ of $\mathrm{CO}_{2}$ 
in terms of global climate change reduction potential [9];

(c) Replacement of fossil fuels for thermal and electric energy, such as petroleum, nuclear, coal and natural gas [9];

(d) Replacement of fossil fuels for mobility, as diesel and gasoline. Biogas can be upgraded and converted into biomethane, which has a GHG reduction potential of $96 \%$ compared to diesel and 97\% compared to gasoline [12] (Fig. 2);

(e) As by-product of biogas production, the digestate can be used as an organic fertilizer for crops and soil improvement, building and maintaining healthy and productive soils needed for sustainable food production. With this, costs and emissions of artificial fertilizers can be saved and mitigated. Evaluations have shown that $13 \mathrm{~kg} \mathrm{CO}_{2}$ equivalent per ton $\left(\mathrm{CO}_{2}\right.$ eq/ton) can be saved when digestate replaces mineral fertilizer [12];

(f) Reduction of odor and pathogenic vectors in the farms, as they are extensively mitigated during the digestion process. In an anaerobic digester, volatile organic compounds are reduced to $\mathrm{CH}_{4}$ and $\mathrm{CO}_{2}$, which are odorless gases. Biogas plants also serve as a method of waste and sewage disposal [11];

(g) Improvement of animal health. The feedlots and dairies that use anaerobic digestion facilities are also healthier from a nutrient management and animal health perspective [12];

(h) Smaller physical footprint for organics waste processing versus composting [9].

\subsubsection{Economic Benefits}

Besides mitigating environmental impacts on livestock activities, biogas can also provide economic benefits for farmers, supply chain and local communities, such as:

(a) Avoiding costs of on-site electricity, heat, transportation fuel and fertilizer, as biogas will produce both products inside the farm, providing more competitiveness in the activity. The average of electric energy tariff for Brazilian agribusiness is still higher than in other countries. The study named "how much electricity for industry in Brazil costs", carried out by the Federation of Industries of the State of Rio de Janeiro (FIRJAN) indicates that the national average tariff is $99.0 \mathrm{USD} / \mathrm{MWh}$, about $25 \%$ above the average for 28 other countries [13];

(b) Promotion of new income for the farmers, as they can locally sell electric, thermal and vehicular energy, and also fertilizer. The biogas can be used on-site to offset energy costs, and can also be sold to utilities to promote a more resilient and diversified energy system composition [9];

(c) With energy security. The production of biogas is less sensitive to climate changes, constituting a firm and safe source of energy with the expected quality. Climate change has altered the hydrological cycle (evaporation-precipitation), inducing the reduction of water levels in the reservoirs in atypical periods, which also contributes to increase the risk of energy shortages for those countries, such as Brazil that has a

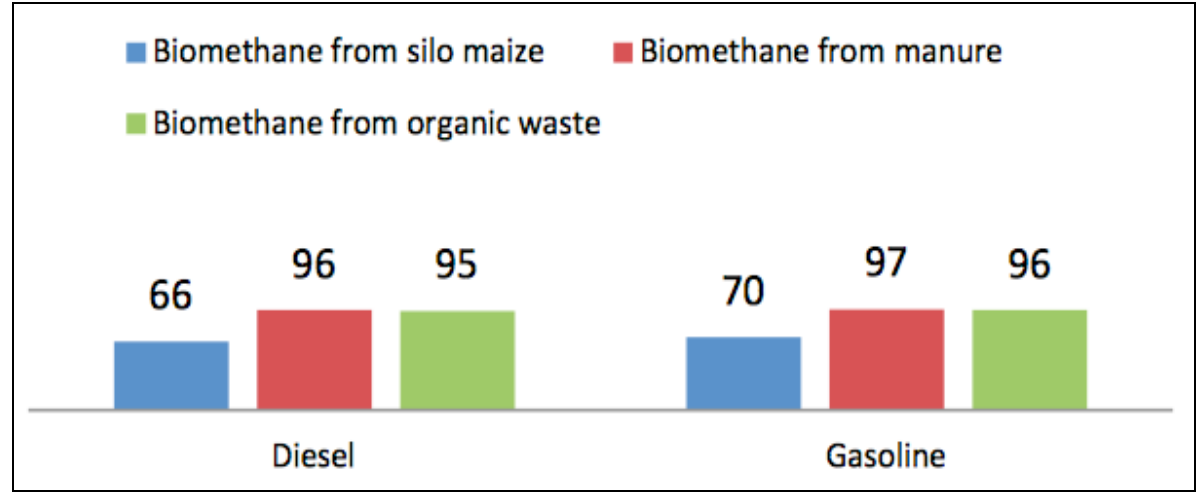

Fig. 2 GHG emissions reduction potential of biomethane in \% as compared with diesel and gasoline. Source: European Biogas Association [12]. 
significant part of its energy matrix (around 15\%) based on hydroelectricity and therefore the economic development of the sector and society [14];

(d) Motivating economic development in the community, generating a lot of investment in rural communities, improving the biogas supply chain in the area and also improving local infrastructure and power quality [9];

(e) Local job creation in technical, manufacturing and construction/trades [11].

\subsubsection{Social Benefits}

Biogas can also provide benefits in social aspects, as discussed below:

(a) Environmental awareness for its collaborators and neighboring communities, since they will be involved in sustainable methods of production and energy, carrying out daily activities thinking about saving natural resources;

(b) The processing of animal manure in biogas system obviously improves sanitary conditions in the locality. The initial pathogenic potential of the raw materials is greatly reduced by the digestion process, since most of the diseases causing microbes are aerobic in nature [11];

(c) Improve rural infrastructure for waste management and distributed energy delivery, enhancing community health, resiliency and viability [12];

(d) Biogas system can also play a vital role in helping communities adapt to and become more resilient to the effects of climate change. The distributed nature of the biogas systems can increase the reliability of critical services, such as food, energy, waste management, wastewater treatment and transportation, during and after disasters [9];

(e) Employment generation during the construction phase of biogas systems and also after the implementation, mainly for maintenance and operation of the system [12];

(f) Professional training of employees: provision of skills enhancement and employment for rural areas.
To the extent that the introduction of biogas technology generates jobs and higher income while improving living conditions, it may be presumed that fewer rural inhabitants will be drawn away to urban centers to search for a job [11];

(g) Technological development in the region and partnership with several educational institutions, national and multinational companies.

\subsection{Limitations}

Besides all the biogas benefits presented on the environmental, economic and social aspects, there are some limitations associated with the implementation of farm-based biogas that need to be considered as well. The upfront capital investment is reasonably high, about 7,613 USD for 1,000 swines [15, 16], 289,000 USD for 1,000 dairy cows [14], or 1,200 USD for 1,000 broilers [17], and although the life cycle benefits may exceed the initial cost, many medium and small-scale farmers can not afford the initial investment without grants or private financing sources. Furthermore, biogas processes require certain technical skills to operate and maintain, which many farmers do not have. The current technology requires a certain, larger sized farm in order to produce biogas in a usable quantity.

Additionally, unlike wind or solar technology, for which the developer can choose the best location, biogas systems have to be located on or near the farm, which is fixed in location. Consequently, the technology and the energy produced by the technology are located far away from the electricity grid. So if the farmer wants to create the additional revenue by selling electricity, it will also be necessary to invest in extensions from the grid to the farm, further enhancing the process.

Facing these challenges, one option is to create a biogas condominium composed by small-scale farmers, which together can make the biogas system possible and have mutual gains. One reference example was developed by Itaipu Binational and the 
International Center of Biogas, located in Foz do Iguaçu, Paraná State, Brazil, and will be presented in the next section.

\section{Livestock and Biogas Potential in Brazil and the US}

The population growth prediction until 2050 points that the world consumption of meat will have a significant increase: $206 \%$ of poultry, $56 \%$ of pork, and $47 \%$ of beef [18]. This scenario certainly demands greater production of grains to feed the animals, impacting the whole agricultural sector: $148 \%$ increase in soybean production, $117 \%$ corn and $49 \%$ rice [18]. In order to mitigate the environmental impacts caused by these activities, the use of biogas technologies is very important and can bring benefits for the whole supply chain, such as farmers, agroindustry, providers and local community. The following sections will present the livestock biogas potential in Brazil and in the US, mainly poultry, swine and cattle manure, as they are among the largest productions in both countries' livestock.

\subsection{Livestock and Biogas Potential in Brazil}

Brazil stands out among the largest food producers in the world, presenting several advantages related to the availability of water and arable land, appropriate technology to tropical and subtropical regions, rich biodiversity, large territorial extension with variations of climate, etc..

The agribusiness sector accounts for $23 \%$ of gross domestic product (GDP) in Brazil, representing the most competitive sector of the Brazilian economy, with $69.5 \%$ coming from agriculture and $30.5 \%$ from livestock [19]. The sector strongly contributes to the positive results of the Brazilian trade balance, representing $40 \%$ of exports and accounting for $24 \%$ of the country jobs.

Currently, Brazil stands out as the main world producer of sugar, coffee and orange juice, the second of soybean and beef, and the fourth of poultry meat, corn and pork. It is still the world's first exporter and sugar, coffee, orange juice and poultry, according to Table 2.

Exports of Brazilian agribusiness products are expected to expand in the next 10 years. Among the products with the highest export growth potential in this period are pork, beef and poultry meat. Besides this prediction, by 2023 the country will be the fifth largest grain producer, behind USA, China, European Union and India [18].

This scenario is very conducive to biogas use, as these production levels generate a meaningful amount of animal and vegetable wastes that can be converted into energy. The Paraná State Industry Federation (FIEP) [20] analyzed the biogas potential in the Brazilian livestock sector, and updating the data to 2015, it is likely to conclude that the country could

Table 2 Brazilian position in the ranking of production and export of the main commodities, and main buyers countries, in 2014.

\begin{tabular}{|c|c|c|c|}
\hline \multirow{2}{*}{ Product } & \multicolumn{2}{|c|}{ Brazilian position } & \multirow{2}{*}{-Main buyers } \\
\hline & Production & Export & \\
\hline Sugar & $1 \mathrm{st}$ & $1 \mathrm{st}$ & China \\
\hline Coffee & $1 \mathrm{st}$ & $1 \mathrm{st}$ & USA \\
\hline Orange juice & $1 \mathrm{st}$ & $1 \mathrm{st}$ & Belgium \\
\hline Soybean & 2nd & $1 \mathrm{st}$ & China \\
\hline Beef meat & 2nd & $1 \mathrm{st}$ & Hong Kong \\
\hline Poultry meat & 3rd & $1 \mathrm{st}$ & Saudi Arabia \\
\hline Corn & 3rd & 2nd & Japan \\
\hline Pork meat & 4th & 4th & Russia \\
\hline
\end{tabular}

Source: Ministry of Agriculture Livestock and Food Supply [21]. 
Table 3 Production of biogas and bioelectricity from livestock in Brazil in 2014.

\begin{tabular}{|c|c|c|c|c|c|}
\hline Category & $\begin{array}{l}\begin{array}{l}\text { Herd } \\
\text { (millions) }\end{array} \\
\end{array}$ & $\begin{array}{l}\text { Manure production } \\
\text { (million ton/day) }{ }^{2}\end{array}$ & $\begin{array}{l}\begin{array}{l}\text { Biogas production } \\
\text { (million } \mathrm{m}^{3} / \text { year) }\end{array} \\
\end{array}$ & $\begin{array}{l}\text { Energy potential } \\
\text { (GWh/year) }\end{array}$ & $\begin{array}{l}\begin{array}{l}\text { Biomethane potential } \\
\text { (million gallons/year) }\end{array} \\
\end{array}$ \\
\hline Poultry (broilers) & $1,772.5$ & $265,881.9$ & $4,852.3$ & $6,938.8$ & $833,197.1$ \\
\hline Swine & 37.9 & $89,134.0$ & $2,570.2$ & $3,675.3$ & $441,333.6$ \\
\hline Cattle (dairy cows) ${ }^{1}$ & 23.1 & $288,306.2$ & 3,998.8 & $5,718.2$ & $686,641.1$ \\
\hline Total & $1,833.5$ & $643,322.1$ & $11,421.3$ & $16,332.5$ & $1,961,171.9$ \\
\hline
\end{tabular}

Source: adapted from Parana State Industry Federation [20].

${ }^{1}$ In this study, it was considered only dairy cows due to the total or partial confinement of these animals, which facilitates the logistics of manure collection, differently, for example, from beef cattle that are essentially created in an extensively way.

${ }^{2}$ The manure production per animal per day was calculated considering $0.15 \mathrm{~kg}$ for broilers, $2.35 \mathrm{~kg}$ for swine and $12.5 \mathrm{~kg}$ for dairy cows [22].

${ }^{3}$ To calculate the biomethane potential it was considered 0.65 , which represents the average of the biomethane conversion (0.5 to $0.8)$, as presented in Table 1.

Table 4 The US position in the ranking of production and export of the main commodities, and main buyers countries, in 2014.

\begin{tabular}{llll}
\hline \multirow{2}{*}{ Product } & \multicolumn{2}{c}{ US position } & Main buyers \\
\cline { 2 - 4 } & Production & Export & Japan \\
\hline Corn & 1 st & $1 \mathrm{st}$ & China \\
Soybean & $1 \mathrm{st}$ & $2 \mathrm{nd}$ & Mexico \\
Poultry meat & $1 \mathrm{st}$ & $2 \mathrm{nd}$ & Canada \\
Beef meat & $1 \mathrm{st}$ & $4 \mathrm{th}$ & Japan \\
Pork meat & $3 \mathrm{rd}$ & $1 \mathrm{st}$ & China \\
Cotton & 3rd & $1 \mathrm{st}$ & Canada \\
Orange & 3rd & $3 \mathrm{rd}$ & China \\
Wheat & 4th & $1 \mathrm{st}$ & \\
\hline
\end{tabular}

Source: Ministry of Agriculture Livestock and Food Supply [21].

generate $11.4 \mathrm{Gm}^{3} /$ year of biogas and 16,332 GWh/year of energy, which represents 3.6 millions ton oil equivalent per year, as presented in Table 3.

Considering the per capita electric power consumption in Brazil of 2,630 kWh/year (taking into account the entire consumption of the city, including residential, industry and commerce consumption, and public lighting) [23], it is enough to power 6.21 million inhabitants per year with this biogas energy. The biomethane potential is 1,961,171 millions of gallons per year, which is equivalent to $1,667.42$ million gallons of diesel or 1,848.34 million gallons of gasoline.

It is essential to observe that the biogas potential presented considers only the quantity of wastes and manure that can be removed from the field. Thus, there is the need for adequacy and development technologies to collect these wastes in the field and to improve the logistics chain in the rural areas.

\subsection{Livestock and Biogas Potential in the US}

The US is one of the world's leaders in food production, essentially in grains and meat. Besides the agribusiness sector represents only $5.7 \%$ of the country's GPD, the amount of food produced is very representative worldwide [24].

Currently, the US is the main world producer of corn, soybean, poultry meat and beef meat. It is still the world's first exporter of corn, pork meat, cotton and wheat (Table 4).

According to the United States Department of Agriculture (USDA) projections, until 2025 the country will remain the world's largest corn exporter, increasing in response to rising global demand for feed grains to support growth in world meat production. Strong global demand for soybeans, 
particularly in China, boosts soybean trade over the projection period. Even though the US soybean exports are projected to rise, Brazil is projected to remain the world's largest exporter of soybean [25].

Regarding the US livestock sector, the predictions are also of increasing demand, reflecting several factors. Feed costs have fallen from recent highs and are projected to rise only moderately over the next 10 years. Also, demand for meats and dairy products in both domestic market and for export are projected to be robust.

As a result, total red meat, poultry and milk production of the US also increases over the next decade. As production increases, consumption of red meats and poultry is projected to rise from about 211 pounds per person in 2016 to 219 pounds in 2025, an increase of $4 \%$ [25].

These circumstances imply a good opportunity for biogas generation in the country, which currently has more than 2,000 sites producing biogas from landfill, livestock and wastewater sectors. Studies from USDA concluded that with the proper support, more than 11,000 additional biogas systems could be deployed in the country. If fully realized, these biogas systems could produce the equivalent of 2.5 billion gallons of gasoline for vehicles, besides reducing methane emissions equivalent to 4-54 million ton GHG/year in 2030 [9]. Table 5 presents the energy potential from biogas derived from livestock manure in the US.
Considering the per capita electric power consumption in the US of $12,988 \mathrm{kWh} /$ year [26], it is sufficient to power around 3.2 million inhabitants per year with this biogas energy. The biomethane potential is 5,128,334.6 millions of gallons per year, which is equivalent to 4,360.21 million gallons of diesel or 4,883.29 million gallons of gasoline. The country has one of the highest electric power consumptions in the world, so the diversification of the electricity matrix is very relevant.

The states that have the highest concentration of biogas production with animal manure are California, Arizona, New Mexico and North Carolina (Fig. 3). In the border between Nebraska, North Dakota, Minnesota and Iowa, there is also a representative biogas production. Biogas from livestock manure has been adopted by California as an eligible project type for the generation of offsets under its statewide cap-and-trade program. This means that there is potentially a developing market demand for offsets from dairy and swine manure digester projects [9].

In this analysis were included dairy cows, pigs and chicken productions. The methane generation was calculated by animal type and manure management system at county level using data from 2007 census of USDA National Agricultural Statistics Service.

Regarding carbon emissions, methane accounts for nearly $9 \%$ of domestic GHG emissions, and 36\% of these emissions come from the agricultural and

Table 5 Energy potential from biogas derived from livestock manure in the US (2014).

\begin{tabular}{|c|c|c|c|c|c|}
\hline Category & $\begin{array}{l}\text { Herd } \\
\text { (millions) }^{2}\end{array}$ & $\begin{array}{l}\text { Manure production } \\
\text { (million ton/day) }\end{array}$ & $\begin{array}{l}\text { Biogas production } \\
\text { (million } \mathrm{m}^{3} / \text { year) }\end{array}$ & $\begin{array}{l}\text { Energy potential } \\
\text { (GWh/year) }\end{array}$ & $\begin{array}{l}\text { Biomethane potential } \\
\text { (million gallons/year) }^{4}\end{array}$ \\
\hline Poultry (broilers) & $8,686.6$ & $1,302,990.0$ & $23,779.5$ & $34,004.8$ & $4,083,220.7$ \\
\hline Swine & 66.0 & $155,162.9$ & $4,474.1$ & $6,398.0$ & $768,255.7$ \\
\hline Cattle (dairy cows) ${ }^{1}$ & 9.3 & $116,250.0$ & $1,612.3$ & $2,305.7$ & $276,850.9$ \\
\hline Total & $8,761.9$ & $1,574,402.9$ & $29,866.0$ & $42,708.5$ & $5,128,344.6$ \\
\hline
\end{tabular}

Source: adapted from Paraná State Industry Federation [20].

${ }^{1}$ In this study, it was considered only dairy cows due to the total or partial confinement of these animals, which facilitates the logistics of manure collection, differently, for example, from beef cattle that are essentially created in an extensively way.

${ }^{2}$ Census of Agriculture [27].

${ }^{3}$ The manure production per animal per day was calculated considering $0.15 \mathrm{~kg}$ for broilers, $2.35 \mathrm{~kg}$ for swine and $12.5 \mathrm{~kg}$ for dairy cows [22].

${ }^{4}$ To calculate the biomethane potential it was considered 0.65 , which represents the average of the biomethane conversion $(0.5$ to 0.8 ), as presented in Table 1. 


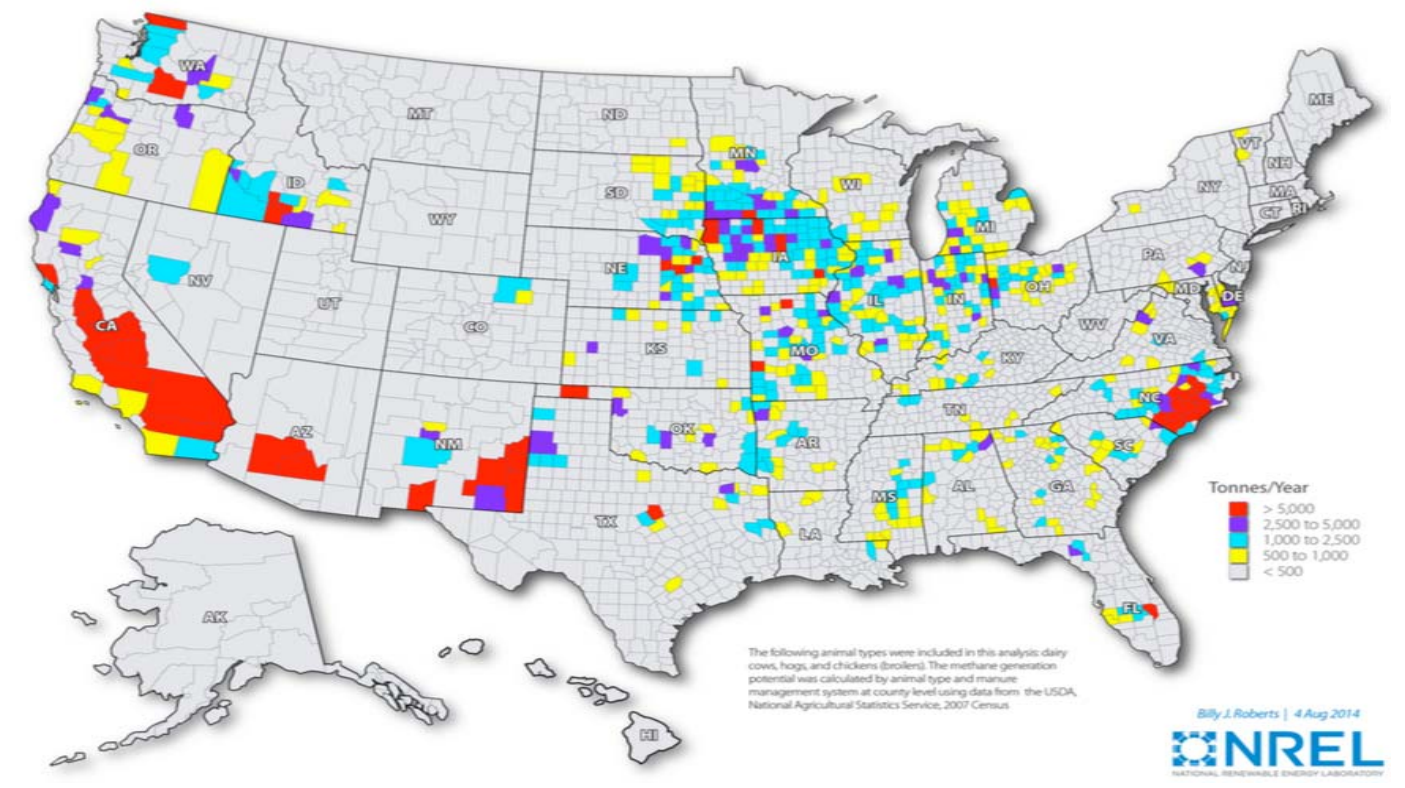

Fig. 3 Methane generation potential from animal manure.

Source: National Renewable Energy Laboratory (NREL) [28].

livestock sectors, equivalent to over 200 million tons of carbon pollution [9]. In 2015, anaerobic digesters on livestock farms reduced GHG emissions by 3.0 million tons of $\mathrm{CO}_{2}$ equivalent, composed by 2.46 million tons of direct methane reductions and 0.56 million tons of emissions avoided. In the same year, energy generation from anaerobic digesters on livestock farms was approximately 981 million $\mathrm{kWh}$ equivalent [29].

There are a number of ways to reduce methane emissions. In the US, the Environmental Protection Agency (EPA) has a series of voluntary programs for this purpose, and is supporting the president's strategy to reduce $\mathrm{CH}_{4}$ emissions. Regarding to agriculture and livestock, methane can be reduced and captured by altering manure management strategies at livestock operations or animal feeding practices, such as biogas process that can significantly reduce methane emission and bring other benefits.

\section{Biogas Condominiums}

4.1 Ajuricaba Agroenergy Condominium for Family Agriculture in Brazil

Located in the West Paraná and at the three-way border between Paraguay, Brazil and Argentina, Itaipu Binational is currently the largest hydroelectric plant in the world in power generation. With 20 generator units and 14,000 MW of installed capacity, it provides $17.3 \%$ of the energy consumed in Brazil and $72.5 \%$ of consumption in Paraguay. In 2016, Itaipu produced 98.6 million MWh, breaking its own world record for energy production [30].

One of the areas of greatest importance for Itaipu Binational is the sub-basin of São Francisco Verdadeiro (SFV), which is inserted in the Paraná III Basin (BP3). The sub-basin has an area of $219.1 \mathrm{~km}^{2}$, comprising 11 municipalities and a population of 262,778 inhabitants. This basin also belongs to the UNESCO Hydrology for the Environment, Life and Policy (HELP) program, an initiative that promotes watershed management worldwide according with sustainability criteria.

Some basin rivers flow into the reservoir of Itaipu hydroelectric. Along this route, the stream and its tributaries pass through small farms, smaller than 30 acres, in a region specialized in transforming vegetable protein into animal protein, specifically swine, cattle and poultry. Consequently, there is a high concentration of animals in a small area and also 
a large concentration of manure. When the manure and other wastes are thrown on the soil without any control related to the dosage and characterization, the pollution of watercourses occurs, causing eutrophication of these waterways and the reservoirs located downstream. Besides this problem, there is also a meaningful emission of methane that is harmful to the environment.

As mentioned before, small-scale farms are usually not able to afford a high investment for biogas systems, so a viable alternative to manage this meaningful amount of manure was to create a condominium system, with small-scale neighbor farmers. Itaipu and other partners concentrated their efforts on the ideals convergence for the emergence of a proposal for sustainability and solidarity economy, which is the implementation of an Agroenergy Cooperative Condominium.

The condominium is located in the city of Marechal Cândido Rondon (Parana State) and is constituted by 25 small properties, each one from 10 ha to 20 ha, producing mainly cattle and pigs, generating approximately $821 \mathrm{~m}^{3}$ of biogas/day, which represents $300,030 \mathrm{~m}^{3}$ of biogas/year. For the appropriate treatment and management of these wastes, 25 digesters and $25 \mathrm{~km}$ of pipelines connected to a thermoelectric micro-center were installed, providing gains to farmers with the production of thermal energy and biofertilizer, which was proved to significantly increase the production of grains [31].

At the first phase of the project, it was projected to generate electric energy through a power generator group of $104 \mathrm{kVA}$, in the distributed generation model, which consists of power generation close to where the demand occurs, being used for self-consumption of the farmers and excess compensation. The electric generation potential was $350 \mathrm{kWh} /$ day, but due to regulatory limitations and lack of incentive, it was necessary to change the project's focus for thermal energy use. In November 2015, the Brazilian Electric Energy Agency (ANEEL) issued the normative resolution (NR) No. 687, amending the NR 482 of April, 2012, and the main result was the permission of micro and mini distributed generation projects, in which the local concessionaire has $30 \mathrm{~d}$ to authorize the generation of energy, and not more than four years, as occurred at the beginning of the project. This delay was crucial for the progress of the electric energy project.

Some of the properties use the biogas as thermal energy in ovens for cooking, in place of liquefied petroleum gas (LPG), and also for heating water for cleaning dairy utensils, improving the quality of milk and consequently, the income generated by its sale. The surplus biogas is being selling for heating boilers at a local cooperative that processes poultries. For its operation, in 2017 it was created an Association of Biogas Producers from Ajuricaba, composed by all these farms [30].

The vehicular application is being studied by upgrading the biogas and converting it into biomethane in substitution of fossil fuels as diesel, natural gas and gasoline. The biogas generated in the digesters is a gaseous fuel with high energy potential. To get the qualified biogas fuel potential, it is required to refine it in different intensities to obtain the biomethane, which is considered a fuel product whose potential is similar to the natural gas.

Research has been conducted for this application, including the development of a biogas rural transport vehicle. Another possibility is the use of biogas in catalytic reforming for hydrogen production, which would bring a greater appreciation of biogas and increase the feasibility of its use. It is also favorable to use the high quality bio-fertilizer, which is applied to pasture or other crops, further increasing the degree of sustainability of the production system.

This arrangement of thermal, electric and vehicular energy use represent a "flexible power plant model" that have a lot of potential in Brazil and in other countries with representative biogas production, such as the US. 
As can be seen, it is possible to transform wastes in a new model for increasing the sustainability of rural properties. Furthermore, all the environmental, economic and social benefits previously described are improving the area and bringing more income for the farmers.

\subsection{Biogas and Biomethane Regulations and} Financial Support in Brazil and the US

A central issue for condominiums feasibility is related to regulations and financial support. In Brazil, biogas and biomethane regulations are being updated and extended in recent years. According to the rules established by ANEEL, through the resolution No. 482/2012, modified by the NR 687/2015, consumers are not allowed to sell the energy to the grid, but they are allowed to install small generators in their consumer units and to use the local electricity system to inject excess energy, which will be converted into a valid energy credit for 60 months. These credits can be used to reduce consumption of the own consumption unit in the following months, in the same ownership, or through an enterprise with multiple consumer units or shared generation, which is the case of biogas condominiums [32].

Regarding biomethane regulations in Brazil, the resolution No. 8/2015, from the National Agency of Petroleum, Natural Gas and Biofuels (ANP) [33], stated that biomethane produced from livestock products and wastes (such as swine and poultry), agricultural and agroindustrial wastes will be treated in the same way as natural gas. This means that biomethane may have the same use of natural gas and have the same economic value, as soon as it meets the product quality requirements of natural gas.

In December 2016, Renova Bio Program was launched in Brazil, in order to foment the advance of biofuels sector in the country until 2030. The program aims to provide economic and financial environmental sustainability, establish marketing rules and invest in new biofuels, such as second generation ethanol, hydrotreated vegetable oil (HVO) biodiesel, cane diesel, biogas, biomethane and bio-kerosene. At the Conference of the Parties 21 (COP-21), the established goal is to reduce GHG emissions to $37 \%$ below 2005 levels by 2025 and 43\% below 2005 levels by 2030 .

The public consultation was opened in early 2017 and the main points suggested for biogas and biomethane project's incentives were:

(a) To define fuel-pricing factor, based on already consolidated methodologies, according to the carbon intensity of the individual life cycle;

(b) To stimulate the production of biogas and the shared generation of energies for groups of small producers via environmental licensing of their activities;

(c) To create specific regulatory environment for flexible plants that allow valuation of the energetic in its various end uses [34].

The perspective is to approve these suggestions in the national congress in the 2nd semester of 2017 and become an important normative in the country.

In the US, with a federal government, each of the 50 states has different regulations and legislative autonomy, but must follow the US constitution. Historically, raw or minimally cleaned biogas has mostly been used to generate electricity to power the facility or sold to the grid. In recent years, rising diesel prices prompted some biogas facilities to upgrade their biogas, generating the biomethane, which can be used for transportation fuel when compressed (CNG) or liquefied (LNG). CNG has been the most common fuel used by fleets, where medium-duty trucks are close to the fueling station, such as city fleets, local delivery trucks and waste haulers. LNG is typically used for heavy-duty trucks traveling along the growing network of LNG fueling stations [9].

Regarding federal regulations about biomethane, EPA has recognized the benefits of supporting low-carbon fuels resultant from biogas, and in a recent rulemaking, EPA classified many sources of biogas as 
cellulosic feedstock for transportation fuels as part of the renewable fuel standard, established by the Energy Policy Act of 2005 and expanded by the Energy Independence and Security Act of 2007 [35].

New pathways include CNG and LNG produced from landfills, municipal wastewater treatment facilities and livestock digesters as well as municipal solid waste. Furthermore, electricity sourced from biogas that is specifically used to power electric vehicles is now qualified for renewable fuel credits [9]. By providing renewable fuel standard credits for electricity produced from biogas, the rule creates an incentive for utilities to invest in renewable fuels.

Biogas producers are allowed to generate renewable identification numbers (RINs), which are tradable certificates whose value is determined in art by market forces, which include compliance targets for specific fuel categories. The biomethane RIN is named D3 and current market prices range from $\$ 0.84$ to $\$ 2.70$ per RIN across all fuel categories [36].

Regarding financial support for biogas projects, the country has some important programs. Some of them are: (1) Rural Energy for America Program, which provides guaranteed loan financing and grant funding to agricultural producers and rural small businesses for renewable energy systems or to make energy efficiency improvements and (2) Advanced Biofuel Payment Program, which support and ensure an expanding production of advanced biofuels.

In Brazil, there is no government subsides for biogas project implementation. There are some special programs related to biogas, such as the Brazil-Germany Project for the Promotion of Biogas Energy Utilization (PROBIOGÁs) in Brazil, which was in force from 2013 to 2016, aiming at expanding the efficient use of biogas in basic sanitation and in agricultural and agroindustrial initiatives, to insert biogas and biomethane in the national energy matrix and thus contribute to the reduction of GHG emissions. To achieve its objectives, PROBIOGÁs focused on: (1) working to improve regulatory conditions; (2) approaching teaching and research institutions; (3) encouraging the national biogas industry.

The program is the result of technical cooperation between the Brazilian government through the National Secretariat of Environmental Sanitation of the Ministry of Cities and the German government through the Deutsche Gesellschaft für Internationale Zusammenarbeit (GIZ) GmbH.

Brazilian government and institutions are elaborating the National Biogas and Biomethane Program, which is expected to be issued this year (2017), and it is the first specific public policy in this sector. This program aims to establish specific conditions for investments in biogas and biomethane, in order to be attractive to potential producers and users and turn biogas and biomethane safe sources of energy, officially inserted in the energy matrix, with stable quality and availability [37].

For financial support for biogas projects implementation, there are some funding programs, such as Low Carbon Agriculture (ABC) Program, which aims to finance investments that contribute to the reduction of environmental impacts caused by agricultural activities, including access to rural technical assistance to promote improvement of infrastructure associated with the technologies offered by agricultural research. The interest rate is $8.0 \%$ per year.

In April of this year, Banco do Brasil (Brazilian Bank) launched the Agro Energy Program, which aims to finance the implementation of plants that generate alternative and renewable energy sources (solar, wind and biogas). Among the financing lines is the National Program for Strengthening Family Agriculture (PRONAF-Eco), which is intended to stimulate income generation and improve the use of family labor for small and medium farms, including investment in renewable energy and environmental sustainability. The interest rate is $2.5 \%$ per year, but limited to 50,000 USD [38]. 


\section{Comparative Analysis between Brazil and the US}

Based on the information presented in the previous sections, it is possible to state that biogas has been recognized as an environmentally friendly renewable source of energy, converting animal manure that could harm the atmosphere into electric, thermal and vehicular energies, besides producing biofertilizer.

Analyzing the data about the potentials for Brazil and the US, it can be concluded that they are among the top countries in livestock production and have a meaningful potential for biogas and biomethane production, as summarized in Table 6 .

The US has a biogas production 2.6 times higher than Brazil, representing good opportunities to reduce fossil fuels dependence and guarantee energy security for the farmers and local communities. The energy potential of biogas in Brazil is enough to meet the needs of 6.21 million Brazilians per year; in the US, it would meet the needs of 3.2 million residents, taking into account that in Brazil the electric power consumption per capita is much lower than in the US (2,630 kWh/year and 12,988 kWh/year, respectively).

Regarding biomethane potential, Brazil could reduce the annual consumption of diesel gallons in 1,667 and in 1,848 of gasoline gallons, mitigating significant environmental impacts. In the US, this reduction is even more expressive, replacing 4,360 gallons diesel and 4,883 gallons gasoline.

These scenarios for both countries represent favorable conditions to implement biogas projects and biogas condominiums that could explore this renewable source of energy, promoting important environmental, economic and social benefits to local population, with implications for rural and urban areas.

Although there is a growing understanding among investors, policymakers, farmers and communities of the importance of investing in biogas systems, there still are significant barriers toward achieving a robust biogas industry in both countries. The first step to implement a biogas system is to locate in the physical space of the sources that will generate biogas, and then determine if it will be activated unitarily or collectively. In this analysis, it is also important to consider the local energy consumption, prioritizing self-consumption, and if there are other consumers close to the enterprise site.

In Brazil and the US, there are a lot of small and medium farms (38\% and 58\%, respectively), and often they are not able to implement and operate a biogas system individually. One possibility presented in this article is the biogas condominium, composed of small and medium scale farms. This arrangement is already being implemented in Brazil, but not yet in the US, and can provide a "win-win" for farmers, communities, environment and project investors. Communities that take appropriate actions to implement biogas systems can improve environmental quality, reduce pollution control costs, mitigate GHG emissions, and generate new income and new jobs, among other benefits, such as providing a balance between energy supply and demand.

Biogas system can also play a vital role in helping

Table 6 Comparison of the livestock biogas potential between Brazil and the US.

\begin{tabular}{lll}
\hline Description & Brazil & US \\
\hline Biogas production (million m³/year) & $11,421.3$ & $29,866.0$ \\
Energy potential (GWh/year of energy) & $16,332.5$ & $42,708.5$ \\
Energy supply (million residents) & 6.2 & 3.2 \\
Biomethane potential (million gallons/year) & $1,961,171.9$ & $5,128,344.6$ \\
Diesel potential (million gallons/year) & $1,667.42$ & $4,360.21$ \\
Gasoline potential (million gallons/year) & $1,848.34$ & $4,883.29$ \\
\hline
\end{tabular}

Source: compiled from various sources presented in the paper. 
communities adapt and become more resilient to the effects of climate change. The distributed nature of the biogas systems can provide important resources during restriction of critical services, such as food, energy, waste management, wastewater treatment and transportation, during and after disasters [9].

Stimulating the use of biogas induces the balance between water, energy and food nexus, not only by the energy produced, but also by the environmental externalities that it triggers. According to Scott et al. [39], "the nexus concept explores interactions of multiple sectors across multiple scales, specifically management of food, water and energy security in local, regional and transboundary settings, and the tradeoffs and synergies created by competing resource use and policy agendas, requiring cross-sector and cross-scalar coordination and integration of resource management and environmental governance”.

\section{Conclusions}

From this research, it can be concluded that biogas systems can support sustainable communities by reducing methane emissions, improving water quality, producing a local source of renewable heat, electricity and fuel, providing local energy security and strengthening the local economy by reducing energy costs and generating revenue. They can provide important benefits to environmental, economic and social areas.

With the biogas potential analysis provided by this study, it is clear that Brazil and the US have substantial opportunities to explore this environmentally friendly source of energy, mainly through biogas condominiums arrangements composed by small and medium scale farms. It was identified that the US has a biogas potential to produce the equivalent of 2.5 billion gallons of gasoline for vehicles and power around 3.2 million inhabitants per year, besides reducing methane emissions equivalent to 4-54 million ton GHG/year in 2030. Brazilian's biogas potential is enough to power
6.21 million inhabitants per year and the biomethane potential is 1,961,171 millions gallons per year, which is equivalent to $1,667.42$ million gallons of diesel or 1,848.34 million gallons of gasoline.

The study concludes that both countries have made important advances in regulations about biogas and biomethane, as these sources can enhance national energy security through diversification in the energy matrix, and help in the GHG emissions reduction.

Through an interdisciplinary arrangement, it is possible to implement agroenergy condominiums, promoting local sustainable development, with benefits for rural and urban areas.

\section{Acknowledgments}

The authors are grateful for International Center of Renewable Energies-Biogas and International Center of Hidroinformatics for the data availability, Pontifical Catholic University of Paraná and Coordination for the Improvement of Higher Education Personnel (CAPES) for funding, and the Udall Center for Studies in Public Policy and other University of Arizona's units for collaboration and technical support.

\section{References}

[1] World Bank. 2015. "Population 2015.” World Development Indicators Database, World Bank. Accessed April 17, 2017. http://databank.worldbank.org/data/download/POP.pdf.

[2] United Nations Water. 2015. "The United Nations World Water Development Report.” Accessed March 11, 2017. http://www.unesco.org/new/en/natural-sciences/environm ent/water/wwap/wwdr.

[3] Pasqual, J. C., Bollmann, H. A., and Scott, C. 2016. "Water-Energy-Food Nexus: Background and Perspectives for Brazil and the United States by 2050.” J. Agri. Sci. Tech. B 6 (2): 108-20.

[4] Rodrigues, R., Santana, C. A. M., Barbosa, A. M., Pena, M. M., and Junior, M. A. G. 2012. "Drivers of Changes in the Brazilian Agri-Food System." Parcerias Estratégicas 17 (34): 7-44.

[5] Eisler, M. C., Lee, M. R., Tarlton, J. F., Martin, G. B., Beddington, J., Dungait, J. A., Greathead, H., Liu, J., Mathew, S., Miller, H., Misselbrook, T., Murray, P., 
Vinod, V. K., Van Saun, R., and Winter, M. 2014. "Agriculture: Steps to Sustainable Livestock." Nature 507 (7490): 32-4.

[6] Metcalf \& Eddy, Inc.. 2003. Wastewater Engineering: Treatment Disposal Reuse, 4th ed.. New York: McGraw-Hill.

[7] National Renewable Laboratory (NREL). 2013. "Energy Analysis: Biogas Potential in the United States.” The US Department of Energy. Accessed October, 2013. http://www.nrel.gov/docs/fy14osti/60178.pdf.

[8] Anderson, B., Bartlett, K., Frolking, S., Hayhoe, K., Jenkins, J., and Salas, W. 2010. Methane and Nitrous Oxide Emissions from Natural Sources. Office of Atmospheric Programs, EPA 430-R-10-001, US Environmental Protection Agency (EPA), Washington.

[9] United States Department of Agriculture (USDA). 2014. "Biogas Opportunities Roadmap: Voluntary Actions to Reduce Methane Emissions and Increase Energy Independence.” US Department of Agriculture, US Environmental Protection Agency, US Department of Energy. Accessed August 2014. https://www.usda.gov/oce/reports/energy/Biogas_Opport unities_Roadmap_8-1-14.pdf.

[10] Coldebella, A. 2006. "Feasibility of Biogas Use in Bovinoculture and Suinoculture for Electric Energy Generation and Irrigation in Rural Properties.” Master thesis, State University of Western Paraná, Brazil. (in Portuguese)

[11] United States Environmental Protection Agency (EPA). 2011. "Market Opportunities for Biogas Recovery Systems at U.S. Livestock Facilities.” EPA, Washington, DC. Accessed November 2016. https://www.epa.gov/sites/production/files/2014-12/docu ments/biogas_recovery_systems_screenres.pdf.

[12] Jones, D. 2016. "EBA's Biomethane Fact Sheet." European Biogas Association (EBA), Brussels, Belgium. Accessed March 11, 2017. http://european-biogas.eu/wp-content/uploads/files/2013/ 10/eba_biomethane_factsheet.pdf.

[13] Vieira, E. E. 2016. "How much Electricity for Industry in Brazil Costs.” Industries Federation of Rio de Janeiro State. Accessed July, 2016. http://www.firjan.com.br/lumis/portal/file/fileDownload.j sp?fileId=2C908A8A559C8BA001563303D3744A1B\&i nline $=1$. (in Portuguese)

[14] Montoro, S. B., Santos, D. F. L., and Lucas Junior, J. 2012. "Economic Analysis of Biogas and Biofertilizer Production by Anaerobic Biodigestion in Dairy Cows Farms.” In Proceedings of the 32nd National Production Engineering Conference, 24-39.

[15] Pasqual, J. C. 2011. "Bioenergy Projects and Carbon Credits: From Liability to Environmental Sustainability in a Swine Property.” Master thesis, Federal University of Santa Catarina, Florianópolis, Brazil. (in Portuguese)

[16] Cervi, R. G., Esperancini, M. S. T., and Bueno, O. C. 2010. "Economic Viability for Electrical Power Generation Using Biogas Produced in Swine Grange.” Eng. Agric. 30 (5): 831-44. (in Portuguese)

[17] Baldin, V. 2013. "Energy Generation in Poultry Production from Manure.” Master dissertation, Federal University of Technology-Parana, Pato Branco, Brazil. (in Portuguese)

[18] Luz, A. 2015. "The World in 2050 and Challenges and Opportunities in Brazilian Agribusiness.” Ministry of Agriculture, Brasília, Brazil. Accessed March 20, 2017. http://docplayer.com.br/9735889-O-mundo-em-2050-e-os -desafios-e-oportunidades-no-agronegocio-brasileiro-anto nio-da-luz-economista.html.

[19] Laplane, M. F. 2014. "Sustainability of Food Production in Brazil: The Role of the Country in the Global Scenario.” Center for Management and Strategic Studies, Brasilia, Brazil. Accessed February 12, 2017. https://www.google.com.br/url?sa=t\&rct=j\&q=\&esrc=s\& source=web\&cd=1\&ved=0ahUKEwjO-9jgwcPUAhWGg pAKHbPGBt0QFggiMAA\&url=http\%3A\%2F\%2Fwww. cgee.org.br\%2Fatividades\%2Fredirect\%2F9157\&usg=A FQjCNH8pe1KDWeOh91eSWStYcQkf3IhkA.

[20] Souza, M., and Schneider, A. H. 2016. "Opportunities of the Biogas Production Chain for the State of Paraná.” Accessed March 2017. http://www.fiepr.org.br/observatorios/download---oportu nidades-da-cadeia-produtiva-de-biogas-para-o-estado-doparana-1-19295-319478.shtml. (in Portuguese)

[21] Ministry of Agriculture Livestock and Food Supply. 2016. "Statistics and Basic Data on Agricultural Economics." Ministry of Agriculture, Brazil. Accessed October 29, 2016. http://www.agricultura.gov.br/agroestatisticas/ estatisticas-e-dados-basicos-de-economia-agricola/estatist icas-e-dados-basicos-de-economia-agricola-abril-2016-1. pdf/view. (in Portuguese)

[22] Tolmasquim, M. 2015. "Statistical Yearbook of Electricity 2015.” Brazilian Company of Energy Research (EPE). Accessed February 12, 2017. http://www.epe.gov.br/AnuarioEstatisticodeEnergiaEletri ca/Forms/Anurio.aspx. (in Portuguese)

[23] Oliveira, A. J., and Ramalho, J. 2006. Brazilian Agroenergy Plan 2006-2011. Brasília, DF: Embrapa Publishing House.

[24] United States Department of Agriculture-Economic Research Service. 2014. "Ag and Food Sectors and the Economy”. Accessed December 3, 2016. https://www.ers.usda.gov/data-products/ag-and-food-stati stics-charting-the-essentials/ag-and-food-sectors-and-theeconomy.aspx. 

Electric, Thermal and Vehicular Energy Use

[25] United States Department of Agriculture. 2016. "USDA Agricultural Projections to 2025.” USDA Agricultural Projections No. OCE-2016-1. Accessed February, 2016. https://www.ers.usda.gov/publications/pub-details/?pubid $=37818$.

[26] World Bank Data. 2014. "Electric Power Consumption (kWh per Capita).” Accessed January 15, 2017. http://data.worldbank.org/indicator/EG.USE.ELEC.KH.P C.

[27] United States Department of Agriculture. 2012. "Census of Agriculture 2012.” Accessed in January 15, 2017. https://www.agcensus.usda.gov/Publications/2012/Full_R eport/Volume_1,_Chapter_1_US/usv1.pdf.

[28] Lusk, P. 1998. "Methane Recovery from Animal Manures: The Current Opportunities Casebook.” National Renewable Energy Laboratory (NREL). Accessed September, 1998. http://www.nrel.gov/docs/fy99osti/25145.pdf.

[29] United States Environmental Protection Agency (EPA). 2015. "Potential for Anaerobic Digestion on Livestock Farms in the United States.” Accessed January 10, 2017. https://www.epa.gov/agstar/agstar-data-and-trends\#adpot ential.

[30] Itaipu Binational. 2016. "Itaipu Surpasses Three Gorges and Is Once Again Global Electric Power Production Leader.” Accessed December 19, 2016. https://www.itaipu.gov.py/en/press-office/news/itaipu-sur passes-three-gorges-and-once-again-global-electric-powe r-production-lead.

[31] International Center of Biogas. 2016. "The First Brazilian Family Farming Community Producing Electric and Thermal Energies, and Biofertizers with Biogas.” Ajuricaba Agroenergy Cooperative. Accessed January 20, 2017. https://cibiogas.org/en/ajuricaba_unit.

[32] Brazilian National Electric Energy Agency. 2015. "ANEEL Extends Possibilities for Micro and Distributed Mini-generation.” Accessed November 24, 2015. http://www2.aneel.gov.br/aplicacoes/noticias/Output_Not icias.cfm?Identidade=8955\&id_area=90.

[33] National Agency of Petroleum, Natural Gas and Biofuels (ANP). 2015. "Resolution No. 8 from ANP.” Accessed January 30 , 2015. https://www.legisweb.com.br/legislacao/?id=280722.

[34] Ministry of Mines and Energy (MME). 2017. "Synthesis of Suggestions Forwarded to RenovaBio, Brasília." $\begin{array}{lll}\text { Accessed } & \text { April } 2017 .\end{array}$ http://www.mme.gov.br/web/guest/apresentacoes?p_p_au th=XGeH8QMD\&p_p_id=20\&p_p_lifecycle=0\&p_p_sta te $=$ normal\&p_p_mode $=$ view\&_20_struts_action=\%2Fd ocument_library\%2Fview_file_entry\&_20_redirect=htt p\%3A\%2F\%2Fwww.mme.gov.br\%2Fweb\%2Fguest\%2 Fconsultas-publicas\%3Fp_p_id\%3D3\%26p_p_lifecycle \%3D0\%26p_p_state\%3Dmaximized\%26p_p_mode\%3 Dview\%26_3_entryClassName\%3D\%26_3_modifiedto \%3D\%26_3_groupId\%3D0\%26_3_modifiedselection\% 3D0\%26_3_keywords\%3Drenovabio\%26_3_documents SearchContainerPrimaryKeys\%3D\%26_3_cur\%3D1\%2 6_3_struts_action\%3D\%252Fsearch\%252Fsearch\%26_ 3_format\%3D\%26_3_modifiedfrom\%3D\%26_3_formD ate\%3D1497656193142\%26_3_modified\%3D\&_20_fil eEntryId=9184384.

[35] United States Environmental Protection Agency (EPA). 2007. "The Energy Independence and Security Act (EISA) of 2007.” Accessed December 19, 2007. https://www.epa.gov/laws-regulations/summary-energy-i ndependence-and-security-act.

[36] Podkaminer, K., Xie, F., and Lin, Z. H. 2017. “Analyzing the Impacts of a Biogas-to-Electricity Purchase Incentive on Electric Vehicle Deployment with the MA3T Vehicle Choice Model.” US Department of Energy, Washington, DC. Accessed January, 2017. http://info.ornl.gov/sites/publications/Files/Pub72437.pdf.

[37] Brazilian Biogas Association (ABiogás). 2015. "Launching of the National Biogas and Biomethane Program Proposal.” Accessed December 7, 2015. https://www.abiogas.org.br/lancamento-pnbb. (in Portuguese)

[38] Brazilian Bank. “Agro Energy Program.” Accessed May 21, 2017. http://www.bb.com.br/pbb/pagina-inicial/ imprensa/n/54949/BB\%20lança\%20programa\%20para\% 20energia\%20limpa\%20e\%20estima\%20liberar\%20R \$\% 202,5\%20bilhões\#/. (in Portuguese)

[39] Grenade, R., House-Peters, L., Scott, C. A., Thapa, B., Mills-Novoa, M., Gerlak, A., and Verbist, K. 2016. “The Nexus: Reconsidering Environmental Security and Adaptive Capacity.” Current Opinion in Environmental Sustainability Journal 21: 15-21. 